\title{
Pengembangan Buku Panduan Konseling Kelompok dengan Teknik Behavior Contract untuk Meningkatkan Tanggung Jawab Akademik Siswa SMK
}

\author{
Dede Ayu Anggraeni*, Ella Faridati Zen, Lutfi Fauzan \\ Universitas Negeri Malang, Jl. Semarang No. 5 Malang, Jawa Timur, Indonesia \\ *Penulis korespondensi, Surel: anggraeenidede@gmail.com
}

Paper received: 3-3-2021; revised: 24-3-2021; accepted: 28-3-2021

\begin{abstract}
This research is a research and development which aims to produce a group counseling manual with the behavior contract technique to increase the academic responsibility of students in vocational schools that are theoretically and practically acceptable. This research procedure adapted Borg and Gall's development model, namely knowing the potentials and problems found, collecting data and information, designing product guides, testing products by experts, and revising the final product. The results of the product trials indicated that the assessment of media experts and potential users stated that the product was "very feasible", while the assessment of the material experts stated that the content of the material in the product was "quite feasible". Thus, it can be concluded that the group counseling guide product with the behavior contract technique to increase the academic responsibility of students in vocational schools has gone through a product expert test based on the acceptance criteria for the format and content of the material.
\end{abstract}

Keywords: group counseling guide; behavior contract; academic responsibility

\begin{abstract}
Abstrak
Penelitian ini merupakan penelitian dan pengembangan yang bertujuan untuk menghasilkan sebuah buku panduan konseling kelompok dengan teknik behavior contract untuk meningkatkan tanggung jawab akademik siswa di SMK yang berterima secara teoritis maupun praktis. Prosedur penelitian ini mengadaptasi model pengembangan Borg dan Gall, yaitu mengetahui potensi dan masalah yang ditemukan, mengumpulan data dan informasi, mendesain produk panduan, menguji coba produk oleh para ahli, dan merevisi produk akhir. Hasil uji coba produk menunjukkan bahwa penilaian dari ahli media dan calon pengguna menyatakan bahwa produk "sangat layak" sedangkan penilaian dari ahli materi menyatakan bahwa isi materi dalam produk "cukup layak". Dengan demikian, dapat disimpulkan bahwa produk panduan konseling kelompok dengan teknik behavior contract untuk meningkatkan tanggung jawab akademik siswa di SMK telah melalui uji ahli produk berdasarkan kriteria keberterimaan format dan isi materi.
\end{abstract}

Kata kunci: panduan konseling kelompok; behavior contract; tanggung jawab akademik

\section{Pendahuluan}

Sekolah Menengah Kejuruan memiliki ciri khas yang berbeda dengan sekolah menengah lain karena di SMK siswa belajar dan praktik industri. Pengertian pendidikan kejuruan menurut UU Nomor 20 Tahun 2003 tentang Sistem Pendidikan Nasional merupakan pendidikan menengah yang mempersiapkan peserta didik untuk siap bekerja dalam bidang keahlian tertentu. Oleh karena itu, SMK memiliki berbagai macam jurusan yang sesuai dengan bidang keahlian siswa. Siswa belajar secara mendalam teori dan praktik di jurusan yang telah dipilih siswa. Siswa belajar secara teori dan praktik dengan seimbang. Seperti di jenjang sebelumnya, siswa diupayakan untuk memiliki catatan prestasi di sekolah baik akademik maupun non akademik. 
Sekolah merupakan rumah kedua seorang anak sebagai pelajar atau siswa. Jika anak di rumah menjadi tanggung jawab orang tua, maka di sekolah siswa menjadi tanggung jawab guru di sekolah. Aminah (Republika.co.id, 2019) menyebutkan bahwa ditemukan tujuh puluh satu siswa SMK asal Bogor bolos hingga ke Banyumas. Berdasarkan artikel berita tersebut, para siswa sengaja membolos sekolah untuk pergi bersama ke Borobudur. Permasalahan tersebut merupakan salah satu bukti bahwa kelompok siswa tersebut tidak memiliki tanggung jawab yang tinggi dalam menjalankan kewajibannya sebagai pelajar yaitu mengikuti pelajaran di sekolah dengan rajin dan sungguh-sungguh. Siswa seharusnya menaati peraturan sekolah meskipun siswa berhalangan hadir dengan tetap memberikan informasi yang jelas dan jujur.

Tanggung jawab sangat dibutuhkan pada diri seseorang dalam proses kehidupan sehari-hari. Tanggung jawab menurut Clemes \& Bean (1995) adalah kemampuan untuk memberikan tanggapan yang berarti mengambil keputusan yang tepat dan efektif. Sikap tanggung jawab yang dapat ditunjukkan siswa yaitu dapat ditunjukkan dengan mengikuti pelajaran di kelas dan menaati peraturan di sekolah. Tanggung jawab utama yang dilakukan siswa adalah tanggung jawab akademik. Siswa dituntut untuk memiliki tanggung jawab terhadap segala hal yang berhubungan dengan akademiknya. Lickona (2004) menyebutkan karakteristik tanggung jawab akademik siswa yaitu berpartisipasi aktif dalam pembelajaran di kelas, melakukan apa yang diharapkan dan menghormati semua orang di sekolah, menggunakan waktu dengan baik, serta menggunakan fasilitas pembelajaran dengan cermat. Oleh karena itu, tanggung jawab akademik perlu ditanamkan sedini mungkin pada diri siswa.

Pengalaman belajar yang dialami siswa dapat mempengaruhi tingkah laku siswa dalam proses kehidupan sehari-hari. Pada keterampilan menghadapi tugas, setiap individu menghadapi tugas atau masalah yang dialaminya dengan cara yang berbeda-beda. Berdasarkan teori belajar behavioristik menurut Desmita (2009) merupakan teori belajar memahami tingkah laku manusia yang menggunakan pendekatan objektif, mekanistik, dan materialistik, sehingga perubahan tingkah laku pada diri seseorang dapat dilakukan melalui upaya pengkondisian. Teori tersebut mengutamakan hasil pengamatan pada terjadinya tingkah laku seseorang. Teori belajar behavioristik berpengaruh terhadap pengembangan teori pendidikan dan pembelajaran yang dikenal dengan aliran behavioristik dimana individu menunjukkan perilaku sebagai hasil belajar.

Berdasarkan data di lapangan, terdapat beberapa siswa yang membolos di saat jam pelajaran berlangsung, bermain gadget saat pelajaran berlangsung, menyontek saat ujian, dan tidur di kelas. Beberapa permasalahan tersebut dapat diketahui bahwa siswa belum memiliki tanggung jawab akademik yang tinggi terhadap kewajibannya sebagai seorang pelajar. Siswa membutuhkan bantuan konselor sekolah agar memiliki tingkat tanggung jawab akademik yang tinggi. Salah satu layanan bimbingan dan konseling yang dapat membantu siswa dalam meningkatkan tanggung jawab akademiknya adalah konseling.

Konseling merupakan suatu proses bantuan yang diberikan konselor kepada konseli atau peserta didik. Konseling dapat dilaksanakan secara berkelompok dengan jumlah anggota yang terdiri dari lima sampai dengan delapan anggota. Konselor bertugas membantu peserta didik agar mencapai pertumbuhan dan tugas perkembangan yang optimal. Peran konselor dalam pelaksanaan konseling cenderung aktif dan direktif agar berfungsi sebagai konsultan dan pemecah masalah (Corey, 2009). Berdasarkan data di lapangan, konselor yang 
memberikan layanan konseling kepada siswa dalam mengatasi kurangnya tanggung jawab akademik pada siswa yaitu dengan tanya jawab sehingga siswa memiliki peluang untuk menunjukkan kembali perilaku yang tidak tepat. Oleh karena itu, diperlukan teknik lain yang sesuai dengan permasalahan siswa agar siswa dapat menyelesaikan permasalahan yang dialami. Teknik behavior contract dipilih sebagai salah satu teknik dalam konseling yang dapat membentuk perilaku baru pada siswa dengan sebuah kontrak.

Kontrak perilaku (behavior contract) adalah perjanjian dua orang atau lebih untuk berperilaku dengan cara tertentu dan untuk menerima hadiah bagi perilaku itu (Fauzan, 2009). Pemilihan teknik behavior contract ini menegaskan adanya harapan dan tanggungjawab yang harus dipenuhi oleh peserta didik dan konsekuensi yang telah dibuat oleh peserta didik tersebut. Berdasarkan uraian di atas, siswa membutuhkan layanan konseling agar siswa bisa lebih bertanggung jawab terhadap akademiknya di sekolah. Oleh karena itu, peneliti mengembangkan sebuah panduan konseling secara kelompok dengan teknik behavior contract yang akan digunakan oleh konselor di sekolah untuk meningkatkan tanggung jawab akademik siswa di SMK. Tujuan penelitian ini adalah untuk menghasilkan sebuah buku panduan konseling kelompok dalam melaksanakan layanan konseling dengan teknik behavior contract untuk meningkatkan tanggung jawab akademik siswa di SMK yang memenuhi kriteria keberterimaan yang terdiri dari aspek ketepatan, aspek kemudahan, aspek kegunaan, dan aspek kemenarikan secara teoritis maupun praktis.

\section{Metode}

Rancangan penelitian yang digunakan dalam penelitian ini adalah penelitian dan pengembangan. Penelitian ini menggunakan model penelitian Borg dan Gall. Pada penelitian ini tidak menggunakan tahap-tahap menurut Borg dan Gall secara keseluruhan. Peneliti tidak seutuhnya menggunakan model pengembangan tersebut. Penelitian dan pengembangan ini menggunakan lima tahap yaitu (1) mengetahui potensi dan masalah yang ditemukan, (2) mengumpulan data dan informasi, (3) mendesain produk panduan, (4) menguji coba produk oleh para ahli, dan (5) merevisi produk akhir.

Pengumpulan data dalam penelitian dan pengembangan ini diperoleh dari pengisian instrumen. Pada penelitian ini, menggunakan dua jenis instrumen, yaitu instrumen need assessment dan instrumen penilaian ahli produk. Instrumen yang pertama adalah instrumen untuk need assessment untuk mengetahui tingkat tanggung jawab akademik siswa di SMK. Instrumen kedua adalah instrumen penilaian produk oleh para ahli. Instrumen kedua berupa format penilaian yang terdiri dari skala penilaian dan lembar kritik dan saran.

Produk pengembangan ini dilakukan uji ahli yaitu ahli media, ahli materi, dan calon pengguna produk untuk mengetahui keberterimaan produk. Para penguji ahli tersebut memberikan penilaian terhadap produk yang dikembangkan peneliti sehingga diketahui kelemahan dan kekuatan dari produk tersebut. Uji coba produk ini sangat membantu peneliti dalam mengembangkan produk yang berkualitas dan bermanfaat. Setelah itu, peneliti melakukan perbaikan atau revisi desain produk atas penilaian yang dilakukan para ahli. Peneliti memahami penilaian dari ahli media dan ahli materi pada produk yang dikembangkan yang nantinya produk ini digunakan sebagai salah satu media konselor dalam memberikan layanan bimbingan dan konseling kepada siswa. 
Data yang diperoleh adalah data angka dan data verbal. Data angka diperoleh dari pengisian instrumen penilaian yang diberikan ahli terhadap produk yang dikembangkan berdasarkan kriteria keberterimaan produk. Sedangkan data verbal diperoleh dari penilaian para ahli berupa saran dan kritik dari subjek uji coba yang diinterpretasikan secara deskriptif. Adapun analisis data angka menggunakan rumus sebagai berikut.

$$
P=\frac{F}{N} \times 100 \%
$$

Keterangan:

$P=$ Presentase nilai yang diperoleh

$F=$ Frekuensi jawaban alternatif

$N=$ Number of case (jumlah frekuensi/ banyaknya individu)

Setelah diketahui hasil perolehan nilai menggunakan rumus di atas, selanjutnya diketahui tingkat kelayakan produk. Terdapat empat kriteria kelayakan produk (Arikunto, 2006). Keempat kriteria kelayakan produk yang dikembangkan oleh peneliti layak untuk digunakan oleh pengguna produk disajikan dalam tabel berikut.

Tabel 1. Kriteria Kelayakan Produk

\begin{tabular}{cc}
\hline Presentase Pencapaian & Interpretasi \\
\hline $76 \%-100 \%$ & Sangat Layak \\
\hline $56 \%-75 \%$ & Cukup Layak \\
\hline $40 \%-55 \%$ & Kurang Layak \\
\hline $0 \%-39 \%$ & Tidak Layak \\
\hline
\end{tabular}

Selanjutnya, pada analisis data verbal menggunakan analisis deskriptif untuk menganalisis dan menginterpretasi instrumen berupa data verbal dari hasil penilaian para ahli terhadap produk panduan berupa kritik dan saran perbaikan. Data tersebut berupa saran dan komentar dari para uji ahli produk panduan konseling kelompok behavior contract untuk meningkatkan tanggung jawab akademik siswa SMK.

\section{Hasil dan Pembahasan}

\subsection{Hasil}

Penelitian dan pengembangan ini menghasilkan sebuah produk berupa panduan konseling kelompok dengan teknik behavior contract untuk meningkatkan tanggung jawab akademik siswa SMK. Produk panduan ini telah melalui tahapan pengkajian format maupun materi yang dilakukan dengan berbagai pertimbangan secara matang. Pengkajian format buku panduan dapat dilihat dari segi tampilan buku, desain buku, dan sistematika buku. Pada pengkajian materi dalam panduan ini menjelaskan tentang orientasi konsep konseling kelompok teknik behavior contract dan tanggung jawab akademik, prosedur pelaksanaan konseling kelompok dengan teknik behavior contract.

Produk panduan konseling kelompok teknik behavior contract untuk meningkatkan tanggung jawab akademik siswa SMK telah melalui uji produk yang dilakukan oleh tiga jenis ahli, yaitu ahli media, ahli materi, dan calon pengguna produk. Analisi hasil penilaian ahli media menunjukkan bahwa produk memiliki indeks uji ahli sebesar 99\% yang termasuk 
dalam kategori sangat tinggi. Berdasarkan tabel kriteria kelayakan produk, produk ini dinilai sangat tepat, sangat mudah, sangat berguna, dan sangat menarik. Selanjutnya, analisis hasil penilaian ahli materi menunjukkan bahwa produk memiliki indeks uji ahli materi sebesar $75 \%$ yang termasuk dalam kategori cukup. Berdasarkan tabel kriteria kelayakan produk, produk ini dinilai cukup tepat, cukup mudah, cukup berguna, dan cukup menarik untuk digunakan. Analisis hasil penilaian calon pengguna produk menunjukkan bahwa memiliki indeks uji ahli sebesar 98\% yang termasuk dalam kategori sangat tinggi dan dapat dinayatakan bahwa produk ini dinilai sangat tepat, sangat mudah, sangat berguna, dan sangat menarik.

Selanjutnya, analisis hasil data verbal dari ketiga ahli menunjukkan bahwa produk ini terdapat beberapa revisi yang harus dilakukan oleh peneliti. Ahli materi menyatakan bahwa produk ini perlu dicermati kembali pada prosedur pelaksanaan konseling agar tujuan dan pelaksanaan konseling dapat berjalan secara maksimal. Penilaian produk oleh calon pengguna menyatakan bahwa produk akan lebih baik apabila isi panduan terdapat ilustrasi gambar. Penilaian produk secara verbal oleh para ahli tersebut sangat membantu peneliti dalam penyempurnaan produk panduan sehingga panduan yang dikembangkan peneliti dapat dikatakan sempurna.

\subsection{Pembahasan}

Produk akhir penelitian dan pengembangan ini berupa buku panduan konseling kelompok dengan teknik behavior contract untuk meningkatkan tanggung jawab akademik siswa SMK yang disusun secara sistematis dan praktis. Produk panduan ini telah melalui pengkajian format maupun materi. Produk panduan ini juga telah melalui proses penilaian oleh para ahli dan revisi produk. Produk yang telah dikembangkan memiliki keberterimaan berdasarkan aspek ketepatan, aspek kemudahan, aspek kegunaan, dan aspek kemenarikan.

Produk panduan ini memenuhi standar, kaidah, dan kode etik perbukuan sesuai dengan UU Nomor 3 Tahun 2017 tentang Sistem Perbukuan. Ukuran buku panduan dicetak menggunakan kertas ukuran A4 (210 mm x $297 \mathrm{~mm}$ ) sesuai standar ISO yaitu International Organization for Standardization. Cover merupakan bagian penting dari sebuah buku karena dengan adanya ilustrasi gambar dan warna yang mendukung, isi dari buku panduan tersebut dapat tersampaikan. Muharrar (2003) mengatakan bahwa ilustrasi cover buku panduan berfungsi selain sebagai perwajahan untuk menimbulkan daya tarik, juga sekaligus sebagai penjelas isi buku. Pendapat Muharrar tersebut mendukung ilustrasi gambar pada buku panduan ini mampu menggambarkan isi dan tujuan dari isi panduan tersebut.

Panduan ini menggunakan Bahasa Indonesia dengan Ejaan Yang Disempurnakan sehingga pengguna produk dapat memahami makna yang ada di dalam panduan tersebut. Sususan teks dan bahasa sangat penting bagi pembaca untuk memahami isi panduan konseling kelompok teknik behavior ini untuk meningkatkan tanggung jawab akademik siswa SMK. Hal tersebut didukung dengan pendapat Sitepu (2012) yang mengungkapkan bahwa dalam penyusunan buku teks perlu memperhatikan penggunaan bahasa. Oleh karena itu, penggunaan Bahasa Indonesia yang baik dan benar sangat diperhatikan dalam menyusun panduan ini karena panduan ini memudahkan konselor dalam memberikan layanan kepada siswa di sekolah. 
Kemenarikan buku panduan sangat penting untuk diperhatikan sebagai daya tarik pertama bagi pembaca. Adanya aspek kemenarikan dari buku panduan ini pembaca langsung tertarik dari elemen warna, kombinasi warna, dan desain layout pada buku panduan. Perpanduan warna yang seimbang akan menghasilkan warna yang kontras. Hal tersebut didukung oleh pernyataan Ami, dkk., (2012) yang menjelaskan bahwa kontras warna pada buku saku merupakan bentuk komunikasi non-verbal sehingga dapat menyampaikan pesan secara cepat, lebih mudah, dan lebih bermakna.

Produk panduan konseling kelompok teknik behavior contract untuk meningkatkan tanggung jawab akademik siswa SMK terdiri dari empat bagian yaitu pendahuluan, orientasi konsep, prosedur pelaksanaan konseling, dan evaluasi pelaksanaan konseling. Hikmawati (2016) mengatakan bahwa kegiatan bimbingan dan konseling hendaknya memerhatikan layanan yang diberikan pada klien, menyediakan pendukung kelancaran bimbingan dan konseling, dan melakukan penilaian/evaluasi terhadap klien mulai dari tahap awal sampai tahap akhir proses bimbingan. Pernyataan tersebut mendukung bahwa penyusunan produk panduan ini terdapat evaluasi pelaksanaan konseling yang didukung dengan instrumen evaluasi yang membantu konselor mengukur tingkat keberhasilan pelaksanaan konseling kelompok dengan teknik behavior contract selama proses konseling berlangsung maupun hasil yang diperoleh setelah pelaksanaan konseling.

Uraian materi dalam produk panduan ini menjelaskan materi tentang konseling kelompok teknik behavior contract dan tanggung jawab akademik. Prayitno (2004) mengatakan bahwa materi yang diberikan haruslah baru, menarik, bermanfaat, sesuai kebutuhan, jelas, dan mudah dipahami. Isi materi merupakan bagian penting dalam panduan ini karena panduan konseling kelompok teknik behavior contract untuk meningkatkan tanggung jawab akademik siswa SMK merupakan media BK yang digunakan konselor untuk membantu konselor memberikan layanan konseling kepada siswa.

Berdasarkan uraian pembahasan di atas, dapat disimpulkan bahwa produk panduan konseling kelompok teknik behavior contract untuk meningkatkan tanggung jawab akademik siswa SMK telah memenuhi kriteria keberterimaan produk yaitu ketepatan, kemudahan, kegunaan, dan kemenarikan. Produk ini telah melalui uji coba dari para ahli dan telah melaui revisi produk sesuai penilaian yang diberikan oleh ahli media, ahli materi, dan calon pengguna produk. Dengan demikian, produk ini telah dilakukan penyempurnaan produk sehingga produk dapat diimplementasikan konselor untuk membantu mengatasi siswa yang memiliki tanggung jawab akademik rendah.

\section{Simpulan}

Produk pengembangan panduan konseling kelompok dengan teknik behavior contract untuk meningkatkan tanggung jawab akademik siswa SMK telah melalui uji ahli produk berdasarkan kriteria keberterimaan format dan isi materi panduan agar produk yang dihasilkan layak dan berkualitas. Keberterimaan format panduan diperoleh dari hasil uji ahli media berdasarkan aspek ketepatan, kemudahan, kegunaan, dan kemenarikan. Hasil analisis uji ahli produk oleh ahli media diperoleh data angka dan data verbal. Hasil analisis data angka menunjukkan bahwa perolehan nilai termasuk dalam kategori sangat layak sedangkan hasil analisis data verbal menunjukkan bahwa produk sudah layak untuk digunakan di lapangan. Berdasarkan hasil analisis tersebut, dapat disimpulkan bahwa produk konseling kelompok 
teknik behavior contract untuk meningkatkan tanggung jawab akademik siswa SMK sangat tepat, sangat mudah, sangat berguna, dan sangat menarik diimplementasikan di sekolah.

Produk panduan pengembangan telah melalui uji ahli produk berdasarkan kriteria keberterimaan isi materi. Uji ahli produk dilakukan oleh ahli materi BK khususnya ahli konseling berdasarkan aspek ketepatan, kemudahan, kegunaan, dan kemenarikan. Berdasarkan hasil analisis uji ahli diperoleh data angka dan data verbal. Data angka menunjukkan hasil perolehan nilai yang termasuk dalam kategori cukup layak sedangkan data verbal menunjukkan bahwa isi materi masih terdapat beberapa perbaikan. Dapat disimpulkan bahwa dari produk konseling kelompok teknik behavior contract untuk meningkatkan tanggung jawab akademik siswa SMK telah memenuhi keberterimaan. Isi materi dalam panduan ini menunjukkan bahwa isi materi telah berterima sebagai layanan konseling secara kelompok untuk mengatasi siswa yang memiliki tanggung jawab akademik rendah di SMK.

Berdasarkan hasil penelitian ini, didapatkan saran yaitu: (1) pengembangan panduan ini belum dilakukan uji keefektifan karena terdapat beberapa faktor yang menghambat proses penelitian ini sehingga perlu dilakukan uji keefektifan produk terhadap siswa yang memiliki tanggung jawab akademik rendah secara langsung, dan (2) peneliti selanjutnya dapat mengembangkan panduan konseling kelompok dengan teknik behavior contract untuk mengatasi masalah lain yang sesuai dengan kebutuhan siswa di sekolah.

\section{Daftar Rujukan}

Ami, M. S. (2012). Pengembangan buku saku materi sistem ekskresi manusia di SMA/MA Kelas XI. Berkala Ilmiah Pendidikan Biologi (Bioedu), 1(2), 10-13.

Arikunto, S. (2006). Prosedur Penelitian Suatu Pendekatan Praktik. Jakarta: Rineka Cipta.

Clemes, H. \& Bean, R. (1995). How to Teach Children Responsibility (Terjemahan). Jakarta: Binarupa Aksara.

Corey, G. (2009). Theory and Practice of Counseling and Psychotherapy. Belmont, CA: Brooks/Cole.

Desmita. (2009). Psikologi Perkembangan Peserta Didik. Bandung: PT Remaja Rosdakarya.

Fajar. (2002). Mahasiswa dan Budaya Akademik. Bandung: Rineka.

Fauzan, L. (2009). Memberdayakan Behavior Contract untuk Melesatkan Perkembangan Pribadi. https://lutfifauzan.wordpress.com/2009/08/09/kontrak-perilaku/.

Hikmawati, F. (2016). Bimbingan dan Konseling. PT RajaGrafindo Persada: Jakarta.

Lickona, T. (2004). Character Matters How Help Our Children Develop Good Judgment, Integrity, and Other Essential Virtues. New York: Touchstone.

Muharrar, S. (2003). Tinjauan Seni Ilustrasi. Jurusan Seni Rupa. Fakultas Bahasa dan Seni: Universitas Negeri Semarang.

Prayitno. (2004). Layanan L1-L9. Padang: BK FIP UNP.

Republika.co.id. 13 September 2019. 71 Siswa SMK Asal Bogor Bolos Hingga ke Banyumas website: https://nasional.republika.co.id/berita/pxqc9m384/71-siswa-smk-asal-bogor-bolos-hingga-kebanyumas.

Sitepu, B. P. (2012). Penulisan Buku Teks Pelajaran. Bandung: PT Remaja Rosdakarya.

Sugiyono. (2015). Metode Penelitian Kuantitatif, Kualitatif, dan R\&D. Bandung: Alfabeta. 